\begin{tabular}{|c|c|}
\hline Title & Effect of retarders on flow and strength development of alkali-activated fly ash/plast furnace slag composite \\
\hline Author(s) & Sasaki, Kenta; Kurumisawa, Kiy ofumi; Ibay ashi, Kouhei \\
\hline Citation & $\begin{array}{l}\text { Construction and building materials, } 216,337-346 \\
\text { https://doi.org/10.1016/.conbuildmat.2019.05.022 }\end{array}$ \\
\hline Issue Date & $2019-08-20$ \\
\hline Doc URL & http:/hdl .handle.net/2115/82495 \\
\hline Rights & $\begin{array}{l}\text { @ 2019. This manuscript version is made available under the CC-BY-NC-ND } 4.0 \text { license } \\
\text { http://creativecommons.org/icenses/by-nc-nd/4.0/ }\end{array}$ \\
\hline Rights(URL) & http://creativecommons.org/icenses/by-nc-nd/4.0/ \\
\hline Type & article (author version) \\
\hline File Information & word20181207-20190422.pdf \\
\hline
\end{tabular}

Instructions for use 


\title{
Effect of retarders on flow and strength development of alkali-activated fly ash/blast furnace slag composite
}

Kenta Sasaki ${ }^{\mathrm{a}}$, Kiyofumi Kurumisawa ${ }^{\mathrm{b} *}$, and Kouta Ibayashi ${ }^{\mathrm{c}}$

a: Graduate student, Cooperative Program for Resources Engineering, Graduate school of Engineering, Hokkaido University, Japan.

b: Associate Professor, Division of Sustainable Resources Engineering, Faculty of Engineering, Hokkaido University, Japan.

c: Undergraduate student, Course of Sustainable Resources Engineering, School of Engineering, Hokkaido University, Japan.

*Corresponding author. Tel.: +81 11706 6319; Fax: +81 117066319

E-mail: kurumi@eng.hokudai.ac.jp

\begin{abstract}
Geopolymer concrete presents a major problem regarding its practical application, in that the geopolymer paste has very short setting time. Previous studies have shown that the addition of blast furnace slag to geopolymer paste considerably shortens the setting time. Based on these findings, in the present study, setting retarders were used to lengthen the setting time of the geopolymer paste. The objective of the present study was to identify the effect of a setting retarder on the fluidity and compressive strength of alkali-activated fly ash/blast furnace slag-based materials. It was shown that, by adding a chelator as a retarder, the setting time can be prolonged. However, the setting time was found to be dependent on the type of chelator. Similarly, the compressive strength development of the geopolymer was also found to be dependent on the type of chelator. It was clarified that the concentration of calcium and aluminum in solution during hardening changes with the addition of a chelator, and it was shown that there is a correlation between the concentrations of calcium and aluminum and the setting time.
\end{abstract}

\section{Keywords:}

Geopolymer, Fly ash, Blast furnace slag, Compressive strength, Setting time, Retarder, Chelator 


\section{Introduction}

Cementitious materials such as concrete are widely used in many fields including reinforced-concrete buildings, roads, dams, and bridges. The main component of concrete is cement. However, the process whereby cement is produced is a major source of $\mathrm{CO}_{2}$, a recognized greenhouse gas and a contributor to global warming. Therefore, to reduce $\mathrm{CO}_{2}$ emissions, there is a necessity to reduce cement consumption. It has been reported that around 13.5 trillion tons of $\mathrm{CO}_{2}$ are produced by global cement production every year, which accounts for about $7 \%$ of all greenhouse-gas emissions [1]. To reduce the $\mathrm{CO}_{2}$ emissions of the cement industry, therefore, blended cement is nowadays being widely used. In this product, the cement is partially replaced by by-products such as blast furnace slag and/or fly ash. However, the cement production process remains a major source of $\mathrm{CO}_{2}$ emissions. As mentioned above, the ultimate goal would be the development of a cement-free material and, to this end, geopolymer concrete has been attracting considerable attention. Geopolymers, first developed by Davidovits [2], are alkali aluminosilicate binders formed by the alkali silicate activation of aluminosilicate binders [3]. Geopolymers exhibit comparable or superior mechanical properties to those of Portland cement [4-6]. It is also well known that geopolymers possess excellent fire resistance (relative to organic materials) and acid resistance [7,8]. Although geopolymers have been studied for application as fire-resistant polymers, they have also been studied for use as construction materials [9]. However, when a geopolymer is to be used as a construction material, it is important to be aware of its physical properties, including its compressive strength and workability.

Previous studies have found that geopolymers have a high compressive strength but poor workability compared to cement-based concrete. Most previous studies focused on these two factors. Apha et al. studied the effect of a naphthalene-based superplasticizer (NSP) on the compressive strength and workability of a lignite bottom-ash geopolymer [10]. They concluded that NSP was not effective in a geopolymer system activated with $\mathrm{NaOH}$ and sodium silicate solutions because, at an NSP/ash ratio of more than 0.09 , the strength of the mortar decreased to $40 \mathrm{MPa}$ even though the workability of the mortar was improved. Behzad et al. studied the effects of different plasticizers (SPs) and activator combinations on the workability and strength of a fly-ash-based geopolymer [11]. They concluded that the effect of different SPs on the workability and strength of the fly-ash-based geopolymer is directly dependent on the types of the activator and SPs. A naphthalene-based SP was effective in the case of a sample activated only by a $\mathrm{NaOH}$ solution. Polycarboxylate-based SP was effective in the case of a sample activated by a multi-compound activator $\left(\mathrm{NaSiO}_{3} / \mathrm{NaOH}=2.5\right)$. Chindaprasirt et al. studied the workability and strength of a coarse high-calcium fly-ash geopolymer with extra water or a SP [12]. They mentioned that the strengths of mortars with extra water were consistently higher than those of mortars with the SP. The reduction in the strength of the mortar with SP in comparison to those of mortar with extra water were found to be dependent on the sodium silicate to $\mathrm{NaOH}$ ratio. Hardjito et al. studied the effect of adding a commercially available naphthalene-based high-range water-reducing admixture [13]. They concluded that the addition of the high-range water-reducing 
admixture improved the workability of the fresh concrete, but it had very little effect on the compressive strength in amounts up to approximately $2 \%$ of the amount of fly ash. The aims of these studies were to attain both high strength and good workability. To this end, the flow value was evaluated as an indicator of the workability. Many studies addressed the compressive strength and flow values when using a SP. In contrast, very few studies evaluated the setting time, which is as important as the workability $[14,15,16,17,18]$.

Against this background, the present study focused on the setting time, with chelators being used as setting retarders. The effect of the chelators on the compressive strength and setting time were evaluated for geopolymers based on blast furnace slag and/or fly ash, and activated by a potassium silicate solution.

\section{Experimental}

\subsection{Sample preparation}

The materials used in this study are listed in Table 1. Fly ash (FA) and blast furnace slag (BFS) were used as the aluminosilicate precursors while potassium silicate (PS) was used as the alkali solution. The chemical compositions of these are listed in Table 2. As chelators (CA), HIDS $\left(\mathrm{C}_{8} \mathrm{H}_{7} \mathrm{NO}_{9} \cdot 4 \mathrm{Na}\right)$, EDTA-4Na $\left(\mathrm{C}_{10} \mathrm{H}_{12} \mathrm{~N}_{2} \mathrm{Na}_{4} \mathrm{O}_{8} \cdot 4 \mathrm{H}_{2} \mathrm{O}\right)$, and GLDA $\left(\mathrm{C}_{9} \mathrm{H}_{9} \mathrm{NNa}_{4} \mathrm{O}_{8}\right)$ were used, as listed in Table 3. Three types of CA with different chelating values were selected, as listed in Table 3. The HIDS was produced by Nippon Shokubai [19]. The chelators bind to a metal ion by coordination with a plurality of coordination sites to form a complex and collect the metal ion. Therefore, it is thought that structure formation can be delayed.

The mixing proportions for the specimens are listed in Table 4. CA (in solid content) was added at a ratio of $4.0 \mathrm{wt} \%$ with respect to the amount of alkali activated filler (AF), after which the chelating values were compared. The powders were first mixed for 30 $\mathrm{s}$, after which an activator was added and then mixed for a further $10 \mathrm{~min}$. After mixing, the samples were put in molds measuring $40 \times 40 \times 160 \mathrm{~mm}^{3}$. After curing for 1 day at $20{ }^{\circ} \mathrm{C}$, the samples were demolded and then allowed to cure at $20{ }^{\circ} \mathrm{C}$ in a sealed container (to prevent drying) until the desired degree of aging had been attained.

\subsection{Experimental method}

In the present study, the slump flow value, electrical resistivity, and concentration of the solution was measured for the fresh geopolymer pastes. The compressive strength, degree of reaction of BFS and FA (as determined by SEM observations), and an elemental analysis by EDX were conducted on the hardened geopolymer paste.

\section{(1) Slump flow test}

The slump flow value was determined as specified in JASS15M-103 (shown in Figure 1 , using a cylindrical sample measuring $\varnothing 50 \times 50 \mathrm{~mm}$ ). The slump flow value was measured at $0,30,60,90,120,150$, and 180 min after mixing, as shown in Figure 2.

\section{(2) Measurement of electrical resistivity}

To measure the electrical resistivity, an impedance analyzer (HIOKI IM3570) was used. The size of the electrode plates used for the measurements was $30 \times 30 \mathrm{~mm}^{2}$. These were embedded in the specimen, $30 \mathrm{~mm}$ apart, when the sample was cast. The 
measurements were performed with an applied voltage of $0.1 \mathrm{~V}$, a frequency of $4 \mathrm{~Hz}-5$ $\mathrm{MHz}$, at room temperature $\left(20^{\circ} \mathrm{C}\right)$. The electrical resistivity was determined by calculating the impedance by assuming that the geopolymer is composed of a circuit with a resistor and capacitor in parallel. The electrical resistivity was measured at 0,30 , $60,90,120,150$, and 180 min after mixing.

\section{(3) Measurement of ion concentration in solution}

The $\mathrm{Ca}, \mathrm{K}, \mathrm{Si}$, and $\mathrm{Al}$ concentrations in solution were measured by using ICP. The solutions used for the measurements were extracted by centrifugation from the samples at 30,60, and 90 min after mixing.

\section{(4) Compressive strength test}

The samples used for the measurements were cut down to $40 \times 40 \times 40 \mathrm{~mm}^{3}$. The compressive strength was calculated from the maximum stress divided by the area of the sample surface.

\section{(5) Determination of degree of reaction of FA and BFS from backscattered electron} (BSE) image

The samples used for the observations were cut down to $5 \times 5 \times 5 \mathrm{~mm}^{3}$, and were freezedried to stop the reaction. The dried specimens were immersed in epoxy resin and, once the epoxy hardened, the surfaces were polished using $\mathrm{SiC}$ paper and diamond paste to give a flat surface. The amounts of unreacted blast furnace slag and fly ash were detected, allowing the degree of reaction of the blast furnace slag and fly ash, as well as the amount of reaction product, to be calculated. SEM observations were performed with an applied voltage of $15 \mathrm{keV}$, a working distance of $17 \mathrm{~mm}$, a magnification of 500, and a pixel size of $0.32 \mu \mathrm{m}$. Element analysis was conducted with energy dispersive $\mathrm{X}$-ray analysis (EDX). The points were set close to the unreacted blast furnace slag or fly ash, allowing the $\mathrm{CaO} / \mathrm{SiO}_{2}, \mathrm{Al}_{2} \mathrm{O}_{3} / \mathrm{SiO}_{2}$, and $\left(\mathrm{CaO}+\mathrm{K}_{2} \mathrm{O}\right) / \mathrm{SiO}_{2}$ values to be calculated. The conditions were the same as those used for the SEM observations. The references used to determine the concentration were wollastonite $\left(\mathrm{CaSiO}_{3}\right)$ and orthoclase $\left(\mathrm{KAlSi}_{3} \mathrm{O}_{8}\right)$. In the present study, the target elements were $\mathrm{Ca}, \mathrm{Si}, \mathrm{Al}$, and $\mathrm{K}$. Twenty images were analyzed using a threshold to acquire the fraction of unreacted blast furnace slag (Figure 3 ), and grids $(24 \times 32)$ were set as shown in Figure 4 to acquire the fraction of unreacted fly ash by using a point-counting method [20]. Based on Delesse theory, the degree of reaction $\left(\mathrm{R}_{\mathrm{FA}}\right.$ or $\left.\mathrm{R}_{\mathrm{BFS}}\right)$ and the amount of reacted product $\left(\mathrm{V}_{\mathrm{p}}\right)$ were calculated using the following formulas and assuming no shrinkage of the specimens [21].

$$
\begin{gathered}
\mathrm{R}_{\mathrm{BFS}}=\frac{V_{B F S}^{i}-V_{B F S}^{u}}{V_{B F S}^{i}} \\
\mathrm{R}_{\mathrm{FA}}=\frac{V_{F A}^{i}-V_{F A}^{u}}{V_{F A}^{i}} \\
\mathrm{~V}_{\mathrm{p}}=1-V_{B F S}^{u}-V_{F A}^{u}
\end{gathered}
$$

where $V_{B F S}^{i}$ is the initial volume of BFS, $V_{F A}^{i}$ is the initial volume of FA, $V_{B F S}^{u}$ is the volume of unreacted BFS at the time of measurement, and $V_{F A}^{u}$ is the volume of unreacted FA at the time of measurement. 


\section{Results}

\section{(1) Slump flow test}

Figure 5 shows the results of the slump flow test. A flow value of ' 100 ' indicates that the flow value could not be measured because the sample hardened. The time required for the samples with HIDS and GLDA-4Na to set was 2.5 times longer than that required for the 'NONE' sample. The time required for the sample with EDTA-4Na to set was 1.5 times longer than that required for the 'NONE' sample. The time required for each sample to set was retarded by the presence of a chelator. Specifically, HIDS and GLDA$4 \mathrm{Na}$ were both able to retard the setting time but had little effect on the slump flow value.

\section{(2) Electrical resistivity}

Figure 6 shows the measured values of electrical resistivity. The normalized electrical resistivity was calculated by dividing the values at the time of the measurement by the value at $0 \mathrm{~h}$, for each sample. The electrical resistivity was found to increase over time. The electrical resistivity of the samples with HIDS and GLDA-4Na were higher than that of the 'NONE' sample. This is probably because the ion concentration in the solution is low.

\section{(3) Concentration in solution}

The results obtained for the concentration in solution are shown in Figures 7-10. The $\mathrm{Ca}$ and $\mathrm{Al}$ concentrations of each sample increased over time. The $\mathrm{Ca}$ and $\mathrm{Al}$ concentrations of EDTA-4Na were equal to or greater than that of the 'NONE' sample. The $\mathrm{Ca}$ and $\mathrm{Al}$ concentrations in solution with HIDS were the lowest. The Si and $\mathrm{K}$ concentrations remained the same regardless of whether a chelator is used or the amount of time that is allowed to elapse.

\section{(4) Compressive strength}

Figure 11 shows the results obtained for the compressive strength. The compressive strength was found to increase over time. The compressive strengths of the samples with EDTA-4Na and GLDA-4Na after aging for 28 days were $15 \mathrm{MPa}$ less than that of the 'NONE' sample. However, the compressive strength of the sample mixed with HIDS was the same as that of the 'NONE' sample. It was shown that HIDS did not inhibit the reaction.

\section{(5) Degree of reaction of BFS and FA, and amount of reacted product as determined from BSE image}

Figures 12 to 14 show the degrees of reaction obtained for blast furnace slag (BFS) and fly ash (FA), as well as the amount of reacted product. The degree of reaction of BFS (Figure 12) with EDTA and GLDA-4Na is lower than that of the 'NONE' specimen. That is, the reaction may be inhibited by the presence of these chelators. However, the degree of reaction of FA (Figure 13) was almost the same and increased with the curing period. Therefore, it was shown that the effect of the chelating agent on the reaction was minimal. The amount of reacted product (Figure 14) for all the specimens remained the same regardless of the presence or absence of a chelator. There is very little difference in the range which can be observed with an electron microscope. 


\section{(6) Element analysis by EDX}

Figures 15-17 show the results of the element analysis of reacted product as performed by EDX. The $\mathrm{CaO} / \mathrm{SiO}_{2}$ and $\left(\mathrm{CaO}+\mathrm{K}_{2} \mathrm{O}\right) / \mathrm{SiO}_{2}$ molar ratios (Figure 15 and 16) decreased with the curing time. It is thought that the amount of $\mathrm{SiO}_{2}$ increased as a result of the progress of the fly ash reaction. Furthermore, the $\mathrm{Al}_{2} \mathrm{O}_{3} / \mathrm{SiO}_{2}$ molar ratio (Figure 17) increased with the curing time except in the case of the HIDS sample. The molar ratios in the HIDS sample were higher than those of the other samples. This shows that the reaction in the HIDS sample is accelerating.

\section{Discussion}

\subsection{Effect of chelator on fluidity}

Figures 18-21 show the relationships between the normalized slump flow and the concentration of the solution. Normalized flow values, obtained by dividing the slump flow values by the slump values at $0.5 \mathrm{~h}$, are shown. The slump flow values were found to decrease with the $\mathrm{Ca}$ and $\mathrm{Al}$ concentrations in the solution. The relationship between the $\mathrm{Si}$ and $\mathrm{K}$ concentration and slump flow values were not clear. Therefore, it is likely that the $\mathrm{Ca}$ and $\mathrm{Al}$ affect the slump flow value and setting time. In the sample mixed with HIDS, the setting time became longer because the concentrations of $\mathrm{Al}$ and $\mathrm{Ca}$ were low. It was reported that HIDS form stable water-soluble complexes with various metal ions over a wide $\mathrm{pH}$ range, with the chelating ability of $\mathrm{Fe}^{3+}$ in an alkaline solution being particularly high $[19,22]$. Therefore, it is thought that HIDS forms a complex of calcium or aluminum.

Figures 22-25 show the relationships between the electrical resistivity and concentration in the solution. The normalized electric resistivity obtained by dividing the measured values by the values at $0.5 \mathrm{~h}$ is shown. The electrical resistivity was found to decrease as the $\mathrm{Ca}$ and $\mathrm{Al}$ concentrations increased. In contrast, there is no clear relationship between the $\mathrm{Si}$ and $\mathrm{K}$ concentrations and the electrical resistivity. This also indicates that the $\mathrm{Ca}$ and $\mathrm{Al}$ concentrations greatly influence the structure formation.

\subsection{Effect of chelator on compressive strength}

Figure 26 shows the relationship between the compressive strength and density. The compressive strength was found to be proportional to the density. Therefore, the density has considerable influence on the compressive strength, given that the density is proportional to the amount of air trapped in the specimen. Therefore, it is thought that some chelators generate air in high alkali conditions.

Figures 27 and 28 show the relationship between degree of reaction of BFS and FA and the compressive strength. Figure 29 shows the relationship between the amount of reacted product and the compressive strength. The compressive strength was found to increase with the degree of reaction. In the same way, the compressive strength increased with the amount of reacted product. It can be concluded that the compressive strength increases as space is filled with the reacted product. It has been pointed out that the formation of C-A-S-H contributes to the strength development in a slag-FA system [14,23].

Figures 30-33 show the relationship between the element composition (as determined 
by EDX-element analysis) and the compressive strength. There is no clear relationship between the element composition and the compressive strength. These results show that the air content (density) and the degree of reaction influence the strength development. It has been shown that the strength development can be controlled by using an appropriate chelator.

\section{Conclusion}

The effect of adding chelators as a setting retarder to blast furnace slag and a fly ashbased geopolymer paste was shown to be as follows:

(1) The chelators prolonged the setting time of the geopolymer paste, but the degree of prolongation depends on the type of the chelator that is used. HIDS was shown to be most effective.

(2) It was shown that the strength development also varies depending on the type of chelators.

(3) The concentrations of $\mathrm{Ca}$ and $\mathrm{Al}$ changed over time with the addition of a chelator, while these are also related to the setting time.

Therefore, the setting time was improved by adding a chelator to a geopolymer paste based on blast furnace slag and fly ash. This is extremely relevant to the practical application of geopolymers in engineering.

\section{Acknowledgement}

Part of this research was supported by a Grant-in-Aid for Scientific Research (Kakenhi) [grant number 16K06563].

\section{References}

[1] V.M. Maholtra, Introduction: sustainable development and concrete technology. ACI Concr. Int. 24(7) (2002) 22.

[2] J. Davidovits, Geopolymer Chemistry and Applications, Institute Geopolymere.

[3] P. Duxson, J.L. Provis, G.C. Lukey, S.W. Mallicoat, W.M. Kriven, J.S.J. van Deventer, Understanding the relationship between geopolymer composition, microstructure and mechanical properties, Colloids Surf. A 269 (2005) 47-58.

[4] A. Palomo, F.P. Glasser, Chemically-bonded cementitious materials based on metakaolin, Brit. Ceram. Trans. J., 91 (4) (1992) 107-112.

[5] H. Xu, J.S.J. Van Deventer, The geopolymerisation of alumino-silicate minerals. Int. J. Miner. Process. 59.3 (2000) 247-266.

[6] W.M. Kriven, J.L. Bell, M. Gordon, Microstructure and microchemistry of fullyreacted geopolymers and geopolymer matrix composites. Ceram. Trans. 153.1994 (2003).

[7] J. Davidovits, M. Davidovics, Geopolymer room temperature ceramic matrix for composites. Ceram. Eng. Sci. Proc. 9 (1988) 842-853.

[8] A. Palomo, A. Macias, M.T. Blanco, P.F. Phusical, Chemical and Mechanical Characterization of Geopolymers. In: Proceedings of the 9th International Congress on the Chem of Cem; 1992. p. 505-511. 
[9] J.L. Provis, J.S.J. van Deventer, Geopolymers Structure, processing, properties and industrial applications, CRC Press, Boca Raton Boston New York Washington, DC.

[10] A. Sathonsaowaphak, P. Chindaprasirt, K. Pimraksa, Workability and strength of lignite bottom ash geopolymer mortar, J. Hazard. Mater. 168 (2009) 44-50.

[11] B. Nematollahi, J. Sanjayan, Effect of different superplasticizers and activator activator combinations on workability and strength of fly ash based geopolymer, Mater. Des. 57 (2014) 667-672.

[12] P. Chindaprasirt, T. Chareerat, V. Sirvivantnanon, Workability and strength of coarse high calcium fly ash geopolymer, Cem. Concr. Compos. 29 (2007) 224-229.

[13] D. Hardjito, S.E. Wallah, D.M.J. Sumajouw, V. Rangan, On the Development of Fly Ash-Based Geopolymer Concrete, ACI Mater. J. Title no. 101-M52.

[14] P. Nath, P.K. Sarker, Effect of GGBFS on setting, workability and early strength properties of fly ash geopolymer concrete cured in ambient condition. Constr. Build. Mater. 66 (2014) 163-171.

[15] S. Kumar, R. Kumar, S.P. Mehrotra, Influence of granulated blast furnace slag on the reaction, structure and properties of fly ash based geopolymer. J. Mater Sci. 45.3 (2010) 607-615.

[16] N.K. Lee, H.K. Lee. Setting and mechanical properties of alkali-activated fly ash/slag concrete manufactured at room temperature, Constr. Build. Mater. 47 (2013) 1201-1209.

[17] Salehi, S., Khattak, M.J., Ali, N. and Rizvi, H.R. Development of geopolymerbased cement slurries with enhanced thickening time, compressive and shear bond strength and durability, in IADC/SPE Drilling Conference and Exhibition. Society of Petroleum Engineers. (2016)

[18] Salehi, S., Khattak, M.J., Rizvi, H., Karbalaei, S.F. and Kiran, R. Sensitivity analysis of fly ash geopolymer cement slurries: Implications for oil and gas wells cementing applications, J. Nat. Gas Sci. Eng. 37 (2017) 116-125.

[19] https://www.shokubai.co.jp/ja/products/functionality/hids.html (in Japanese)

[20] X.Feng, E.J. Garboczi, D.P. Bentz, P.E. Stutzman, T.O. Mason, Estimation of the degree of hydration of blended cement pastes by a scanning electron microscope pointcounting procedure. Cem. Concr. Res. 34.10 (2004) 1787-1793.

[21] S. Igarashi, M. Kawamura, A. Watanabe, Analysis of cement pastes and mortars by a combination of backscatter-based SEM image analysis and calculations based on the Powers model, Cem. Concr. Compos. 26.8 (2004) 977-985.

[22] H. Hyvönen, R. Aksela, Complexation of 3-hydroxy-2, 2'-iminodisuccinic acid (HIDS) with $\mathrm{Mg}^{2+}, \mathrm{Ca}^{2+}, \mathrm{Mn}^{2+}, \mathrm{Fe}^{3+}, \mathrm{Fe}^{2+}, \mathrm{Co}^{2+}, \mathrm{Ni}^{2+}, \mathrm{Cu}^{2+}$, and $\mathrm{Zn}^{2+}$ ions in aqueous solution. J. Coord. Chem. 63.12 (2010) 2013-2025.

[23] P. Chindaprasirt, P. De Silva, K. Sagoe-Crentsil, S. Hanjitsuwan, Effect of $\mathrm{SiO}_{2}$ and $\mathrm{Al}_{2} \mathrm{O}_{3}$ on the setting and hardening of high calcium fly ash-based geopolymer systems. J. Mater. Sci. 47.12 (2012) 4876-4883. 
Table1 Materials used in this study

\begin{tabular}{|c|c|c|c|}
\hline \multicolumn{2}{|c|}{} & Material & Physical character \\
\hline \multirow{2}{*}{$\begin{array}{c}\text { AF: } \\
\text { Activated Filler }\end{array}$} & BFS & Blast furnace slag & $\begin{array}{c}\text { Density: } 2.91 \mathrm{~g} / \mathrm{cm}^{3} \\
\text { Specific Surface Area: } 3830 \mathrm{~cm}^{2} / \mathrm{g}\end{array}$ \\
\cline { 2 - 4 } & FA & Fly ash & $\begin{array}{c}\text { Density }: 2.33 \mathrm{~g} / \mathrm{cm}^{3} \\
\text { Specific Surface Area }: 3740 \mathrm{~cm}^{2} / \mathrm{g}\end{array}$ \\
\hline Activator & PS & $\begin{array}{c}\text { Potassium silicate } \\
\text { solution }\end{array}$ & $\begin{array}{c}\text { Density: } 1.58 \mathrm{~g} / \mathrm{cm}^{3}, \text { Concentration } \\
51.0 \mathrm{wt} \%\end{array}$ \\
\hline
\end{tabular}

Table2 Chemical composition of the materials

\begin{tabular}{|c|c|c|c|c|c|c|c|c|c|c|c|c|}
\hline & \multicolumn{10}{|c|}{ Chemical composition (\%) } \\
\cline { 2 - 26 } & $\mathrm{SiO}_{2}$ & $\mathrm{TiO}_{2}$ & $\mathrm{Al}_{2} \mathrm{O}_{3}$ & $\mathrm{Fe}_{2} \mathrm{O}_{3}$ & $\mathrm{MnO}$ & $\mathrm{MgO}$ & $\mathrm{CaO}$ & $\mathrm{Na}_{2} \mathrm{O}$ & $\mathrm{K} 2 \mathrm{O}$ & $\mathrm{P}_{2} \mathrm{O}_{5}$ & $\mathrm{Cl}$ & $\mathrm{S}$ \\
\hline BFS & 33.90 & 0.50 & 14.61 & 1.03 & - & 6.04 & 43.28 & 0.23 & 0.25 & - & - & - \\
\hline FA & 61.7 & 1.23 & 24.0 & 6.1 & 0.08 & 1.11 & 2.57 & 0.82 & 1.51 & 0.78 & - & 0.04 \\
\hline PS & 29.1 & - & - & - & - & - & - & - & 21.9 & - & - & - \\
\hline
\end{tabular}


Table3 Chelator used in this study

\begin{tabular}{|c|c|c|c|}
\hline & Material & Physical properties \\
\hline \multirow{6}{*}{$\begin{array}{l}\text { Chelator } \\
\text { (CA) }\end{array}$} & \multirow[b]{2}{*}{ HIDS } & $\begin{array}{l}\text { 3-hydroxy-2,2'-iminodisuccinic acid tetra } \\
\text { sodium }\left(\mathrm{C}_{8} \mathrm{H}_{7} \mathrm{NO}_{9} \cdot 4 \mathrm{Na}\right)\end{array}$ & \multirow[b]{2}{*}{$\begin{array}{l}\text { Molecular weight: } 353.1 \\
\text { Chelating value: } \\
\text { 300mg- } \mathrm{CaCO}_{3} / \mathrm{g} \\
\text { Solid content: } 50 \mathrm{wt} \%\end{array}$} \\
\hline & & $\overbrace{\mathrm{NaOOC}}^{C_{\mathrm{COONa}}^{\mathrm{N}}}$ & \\
\hline & \multirow[b]{2}{*}{ EDTA-4Na } & $\begin{array}{l}\text { Tetra sodium ethylene diamine tetra } \\
\text { acetate }\left(\mathrm{C}_{10} \mathrm{H}_{12} \mathrm{~N}_{2} \mathrm{Na}_{4} \mathrm{O}_{8} \cdot 4 \mathrm{H}_{2} \mathrm{O}\right)\end{array}$ & \multirow[b]{2}{*}{$\begin{array}{l}\text { Molecular weight: } 452 \\
\text { Chelating value: } \\
221 \mathrm{mg}-\mathrm{CaCO}_{3} / \mathrm{g} \\
\text { Solid content: } 100 \mathrm{wt} \%\end{array}$} \\
\hline & & $\mathrm{NaO}_{2} \mathrm{C} \overbrace{\mathrm{NaO}} \mathrm{C}$ & \\
\hline & \multirow[b]{2}{*}{$\begin{array}{l}\text { GLDA- } \\
4 \mathrm{Na}\end{array}$} & $\begin{array}{l}\text { Tetra sodium L-glutamic acid } \\
\text { diacetate }\left(\mathrm{C}_{9} \mathrm{H}_{9} \mathrm{NNa}_{4} \mathrm{O}_{8}\right)\end{array}$ & \multirow[b]{2}{*}{$\begin{array}{l}\text { Molecular weight: } 351 \\
\text { Chelating value: } \\
115 \mathrm{mg}-\mathrm{CaCO}_{3} / \mathrm{g} \\
\text { Solid content: } 40 \mathrm{wt} \%\end{array}$} \\
\hline & & $\begin{array}{l}\text { GLDA-4Na } \\
\qquad \begin{array}{l}\mathrm{NaOOC} \\
\mathrm{NaOOCCH}_{2} \mathrm{CH}_{2}\end{array}{ }^{\mathrm{CH}-\mathrm{N}}>\mathrm{CH}_{2} \mathrm{COONa}\end{array}$ & \\
\hline
\end{tabular}


Table 4 Mix proportions

\begin{tabular}{|c|c|c|c|c|c|c|c|}
\hline & $\begin{array}{l}\text { Curing } \\
\text { condition }\end{array}$ & Age & $\begin{array}{c}\text { BFS/AF } \\
\text { wt } \%\end{array}$ & $\begin{array}{c}\text { FA/AF } \\
\text { wt } \%\end{array}$ & $\begin{array}{c}\mathrm{PS} / \mathrm{AF} \\
\mathrm{wt} \%\end{array}$ & $\begin{array}{l}\text { W/AF } \\
\text { wt } \%\end{array}$ & $\begin{array}{c}\text { CA(solid } \\
\text { content)/AF } \\
\text { wt } \%\end{array}$ \\
\hline NONE & \multirow{4}{*}{$\begin{array}{c}20^{\circ} \mathrm{C} \\
\text {-Sealed }\end{array}$} & \multirow{4}{*}{ 3,7,28-day } & \multirow{4}{*}{20} & \multirow{4}{*}{80} & \multirow{4}{*}{60} & \multirow{4}{*}{6.0} & \multirow{4}{*}{4.0} \\
\hline HIDS & & & & & & & \\
\hline EDTA-4Na & & & & & & & \\
\hline GLDA-4Na & & & & & & & \\
\hline
\end{tabular}




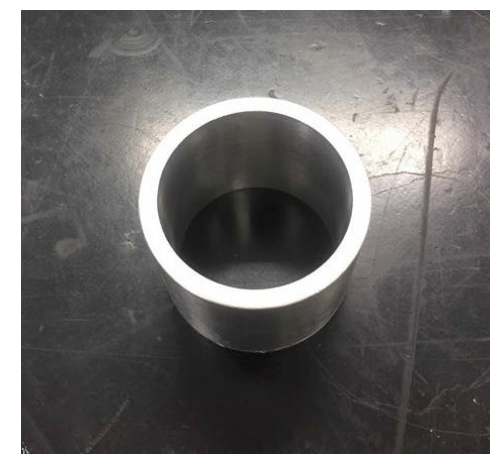

Figure1 JASS15M-103

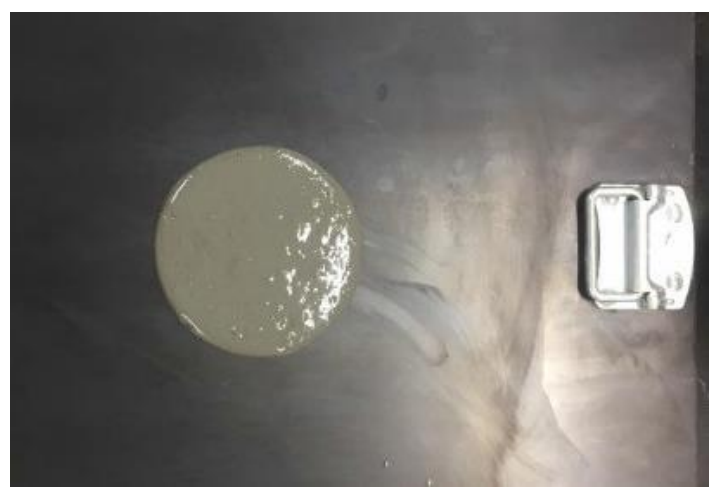

Figure 2 Slump flow test
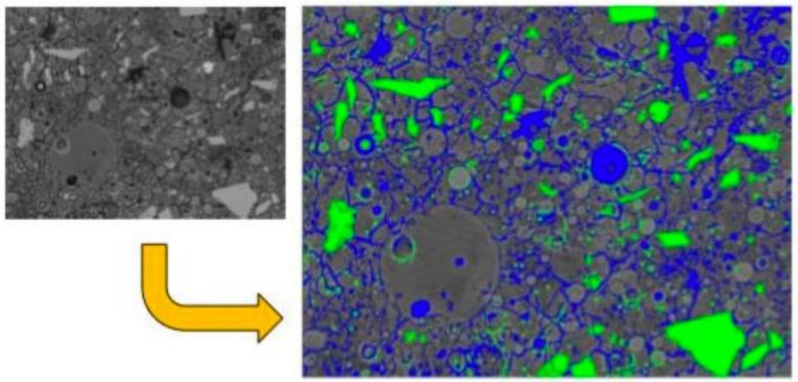

Figure 3 Image applied "threshold" on image J

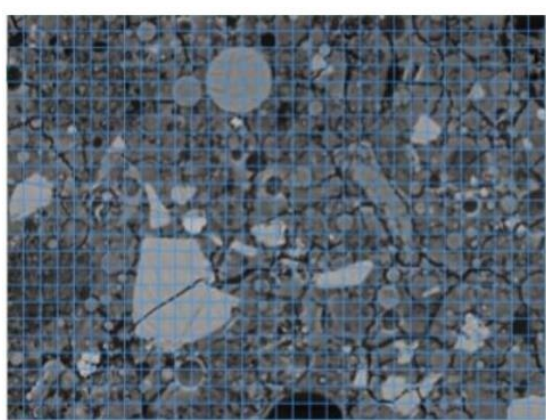

Figure 4 Image set grids for point counting method 


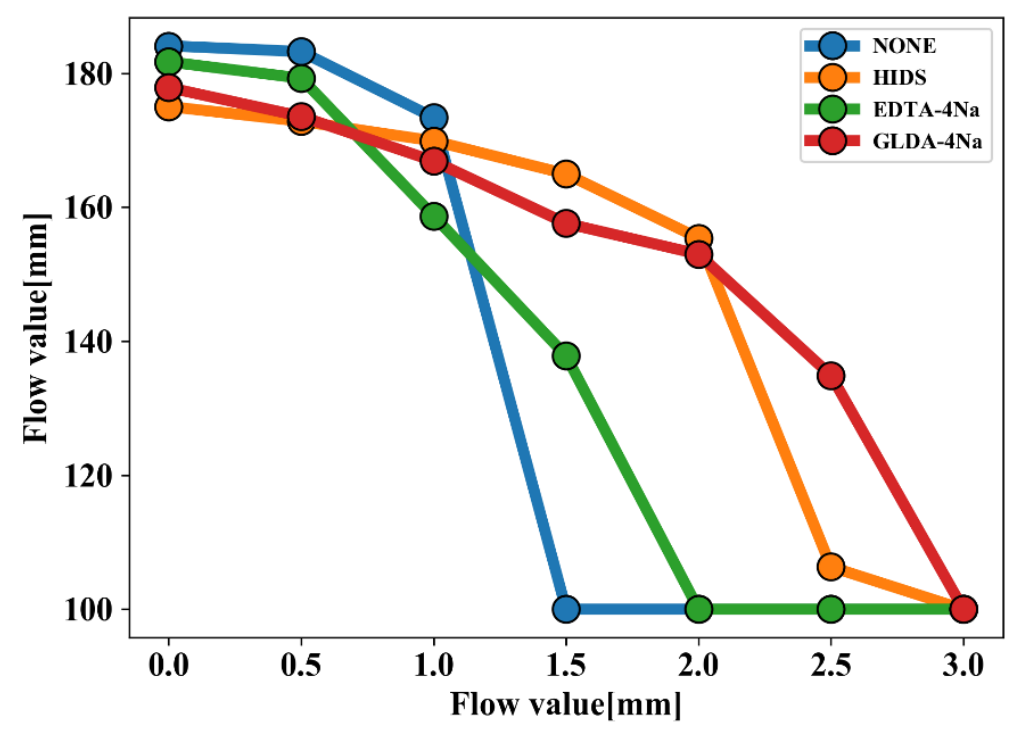

Figure 5 Change of slump flow value with time

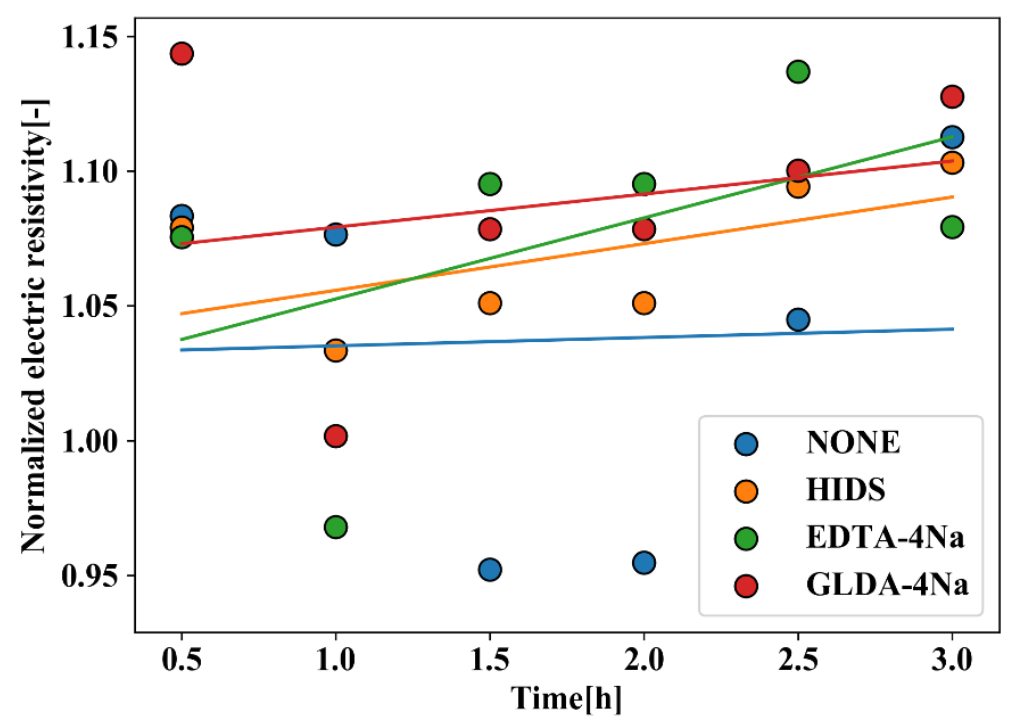

Figure 6 Change of electric resistivity with time 


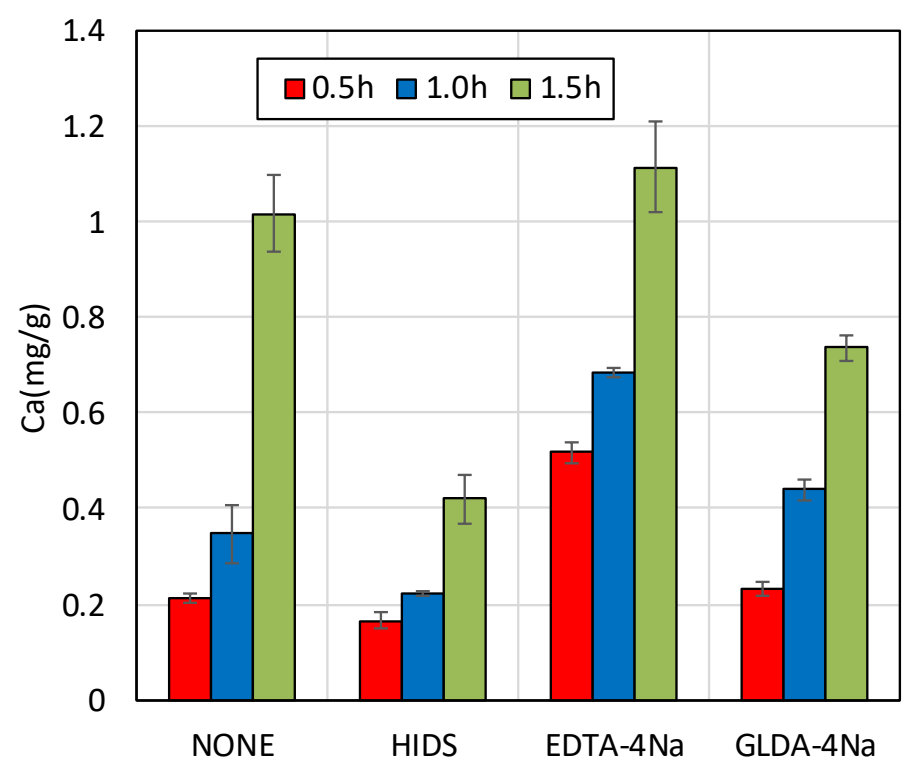

Figure 7 Concentration of $\mathrm{Ca}$ in solution

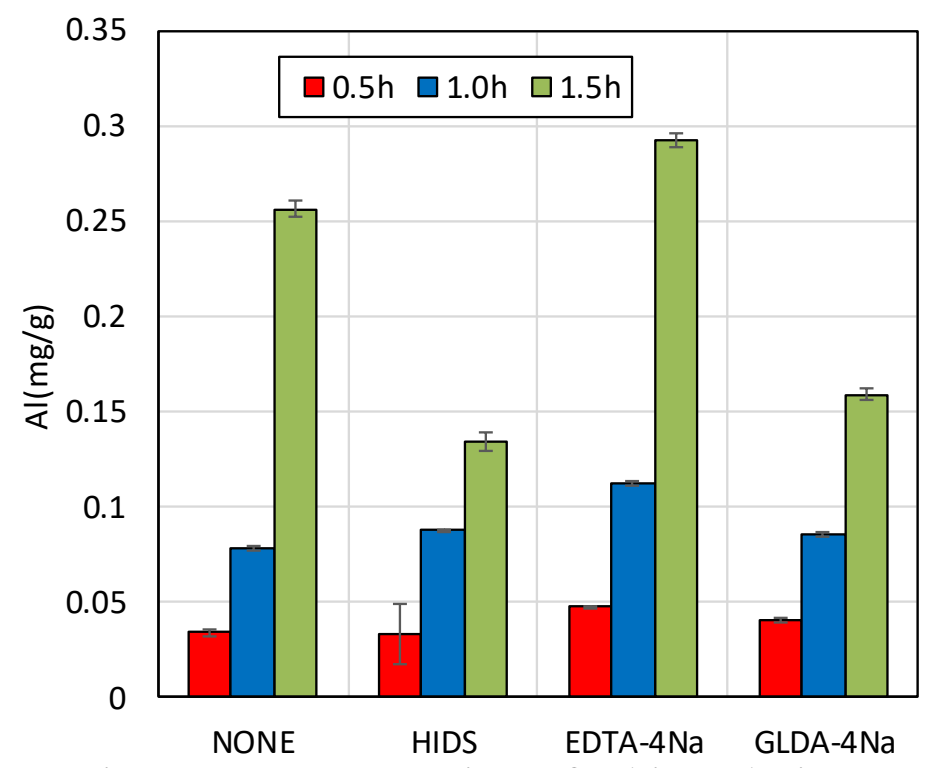

Figure 8 Concentration of $\mathrm{Al}$ in solution

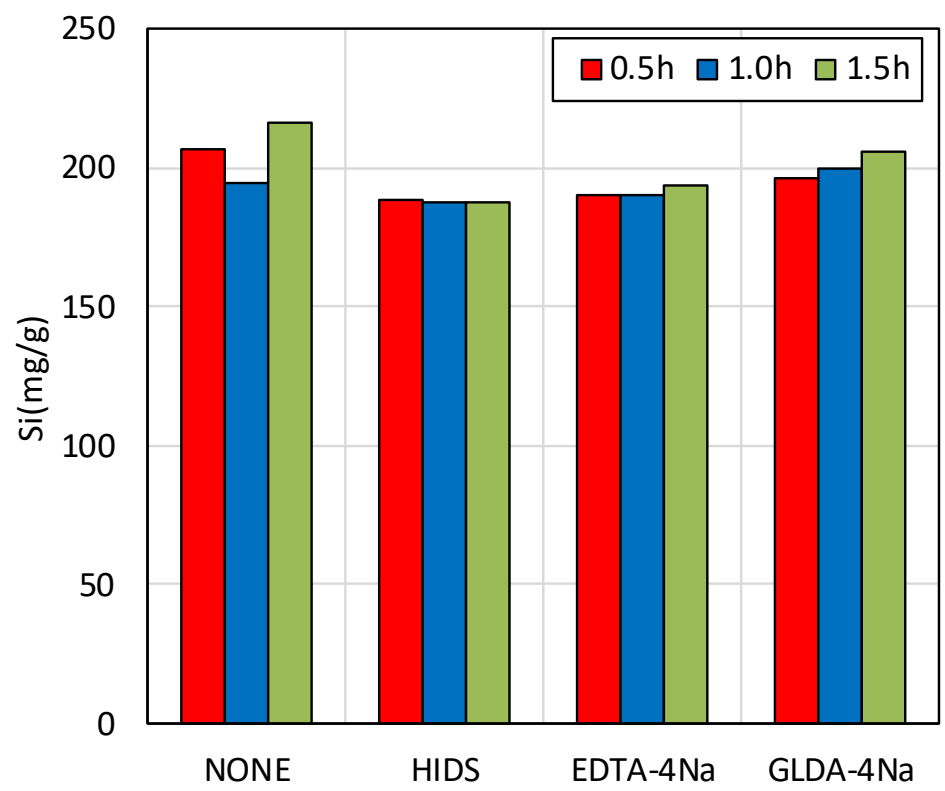

Figure 9 Concentration of $\mathrm{Si}$ in solution 


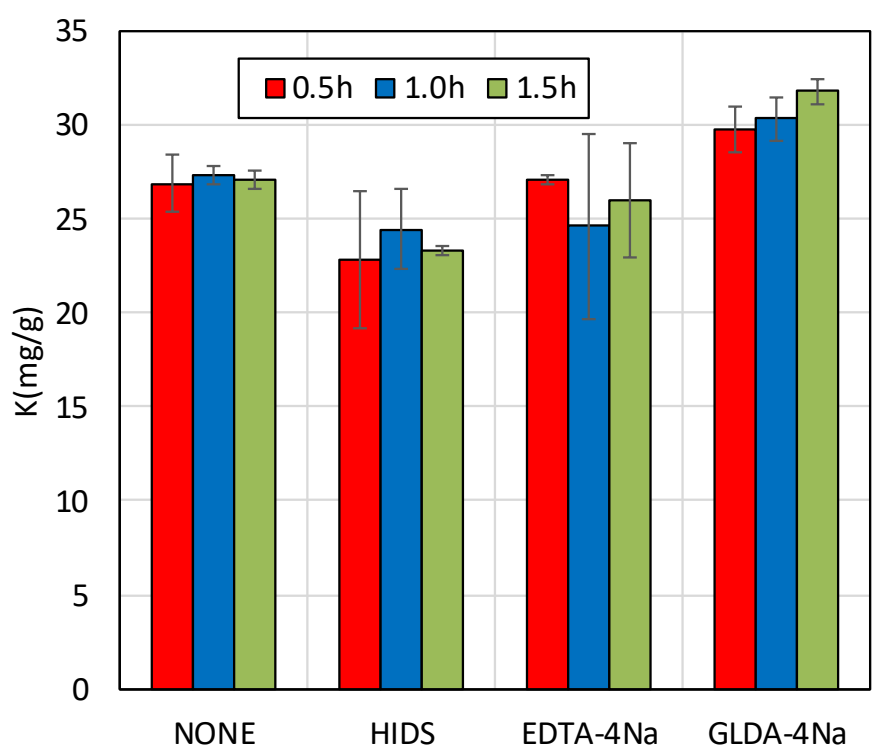

Figure 10 Concentration of $\mathrm{K}$ in solution

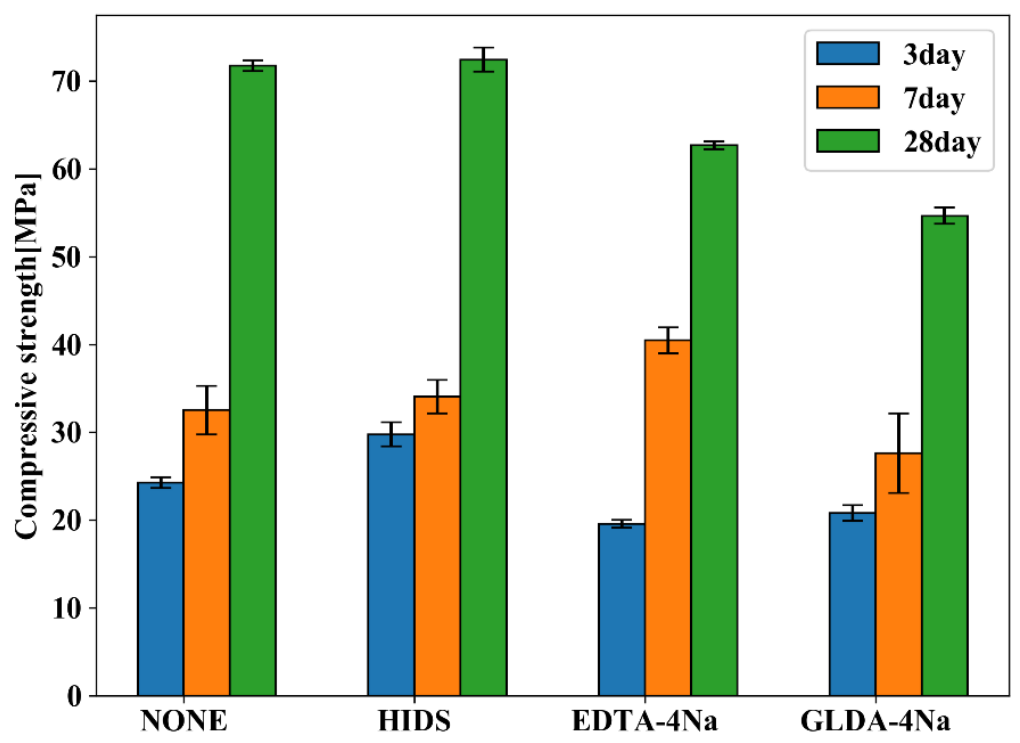

Figure 11 Compressive strength 


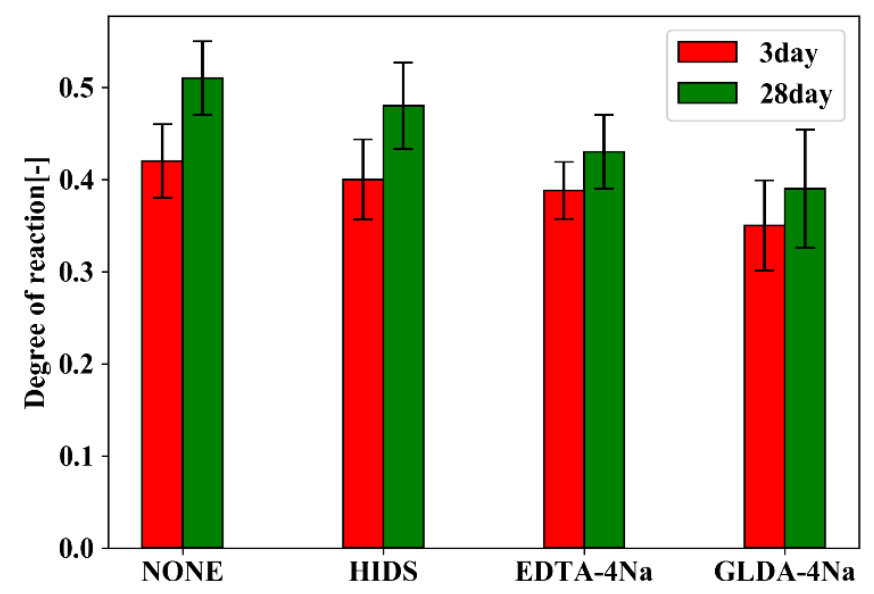

Figure 12 Degree of reaction of blast furnace slag

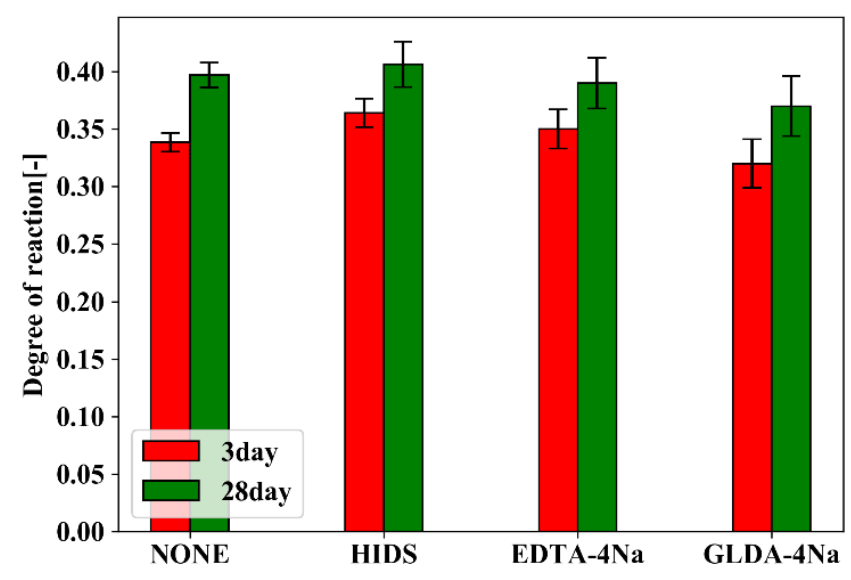

Figure 13 Degree of reaction of fly ash

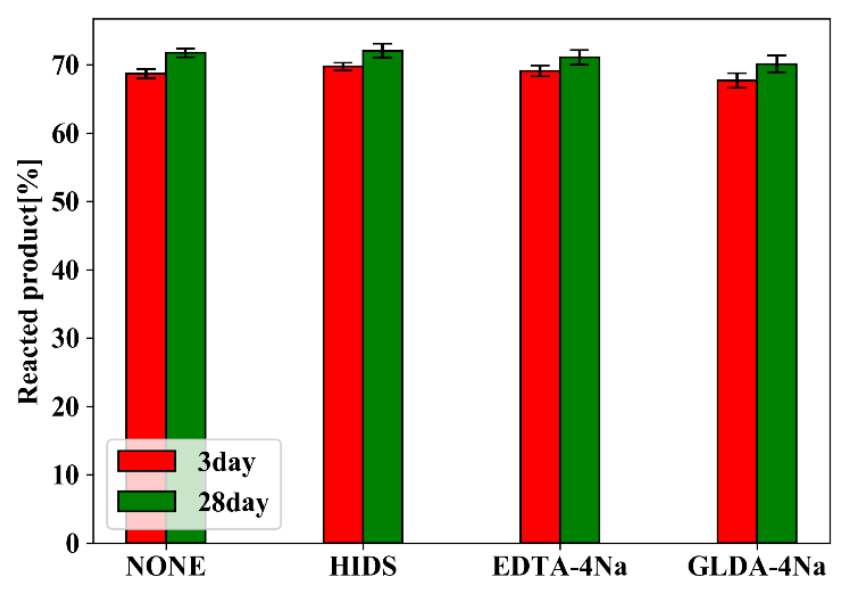

Figure 14 The amount of reacted product 


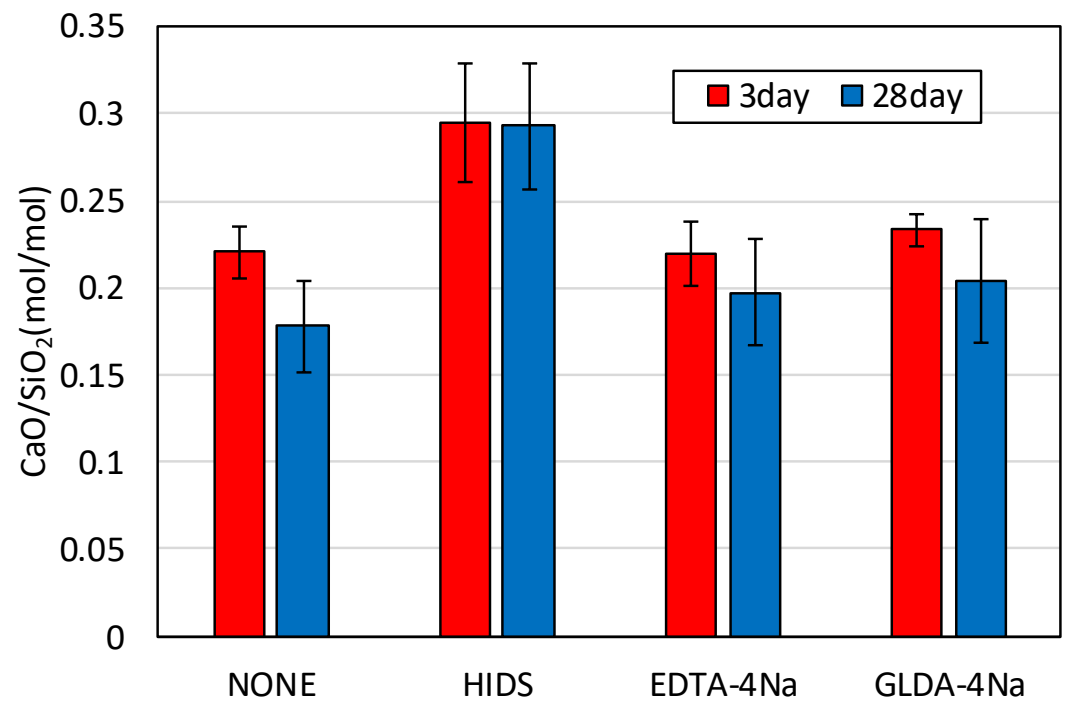

Figure 15 Result of EDX analysis of $\mathrm{CaO} / \mathrm{SiO}_{2}$

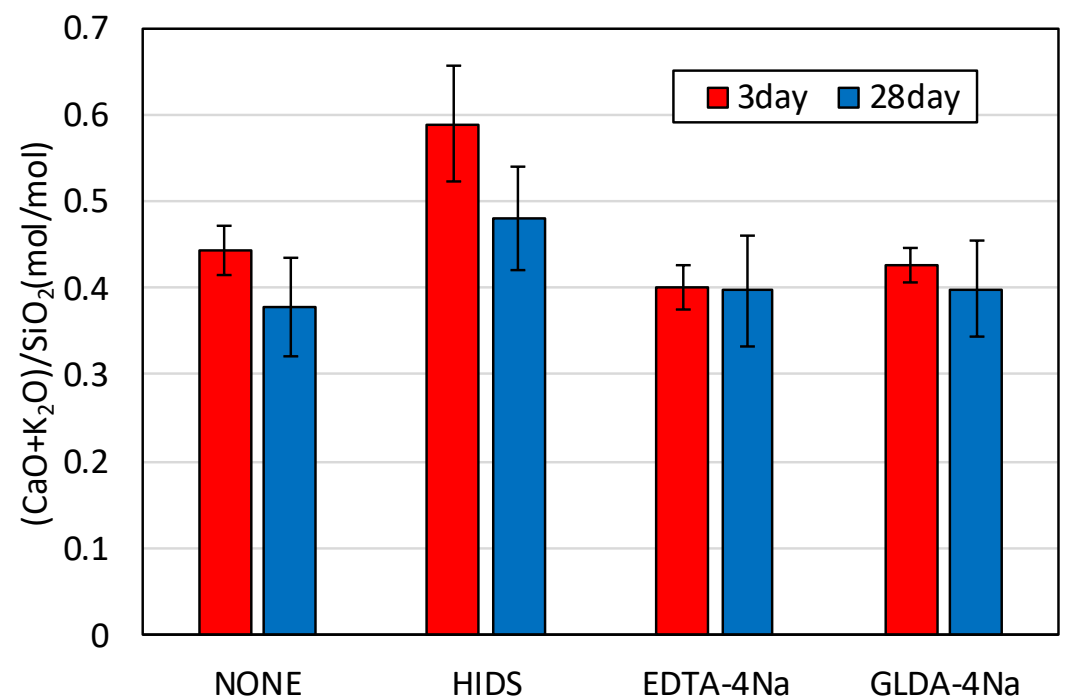

Figure 16 Result of EDX analysis of $\left(\mathrm{CaO}+\mathrm{K}_{2} \mathrm{O}\right) / \mathrm{SiO}_{2}$

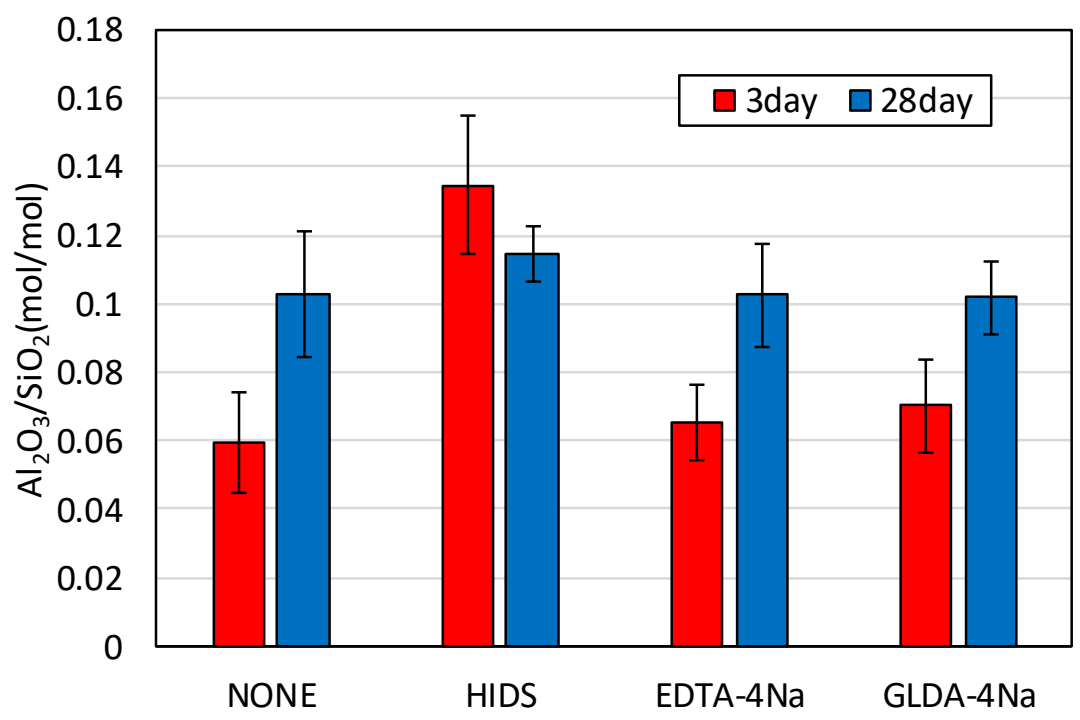

Figure 17 Result of EDX analysis of $\mathrm{Al}_{2} \mathrm{O}_{3} / \mathrm{SiO}_{2}$ 


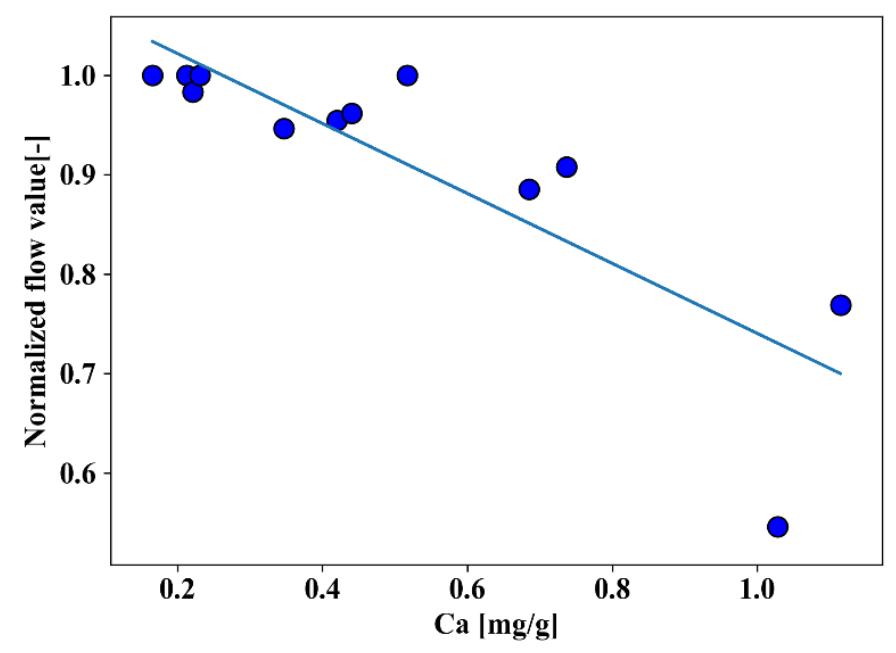

Figure18 Relationship between Ca concentration and normalized slump flow value

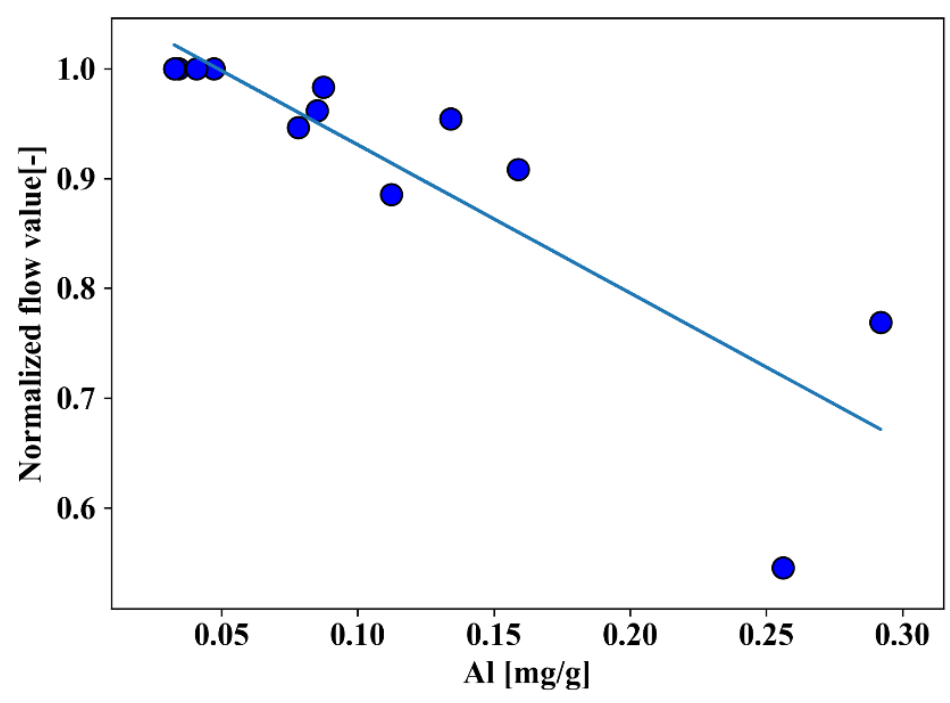

Figure 19 Relationship between Al concentration and normalized slump flow value

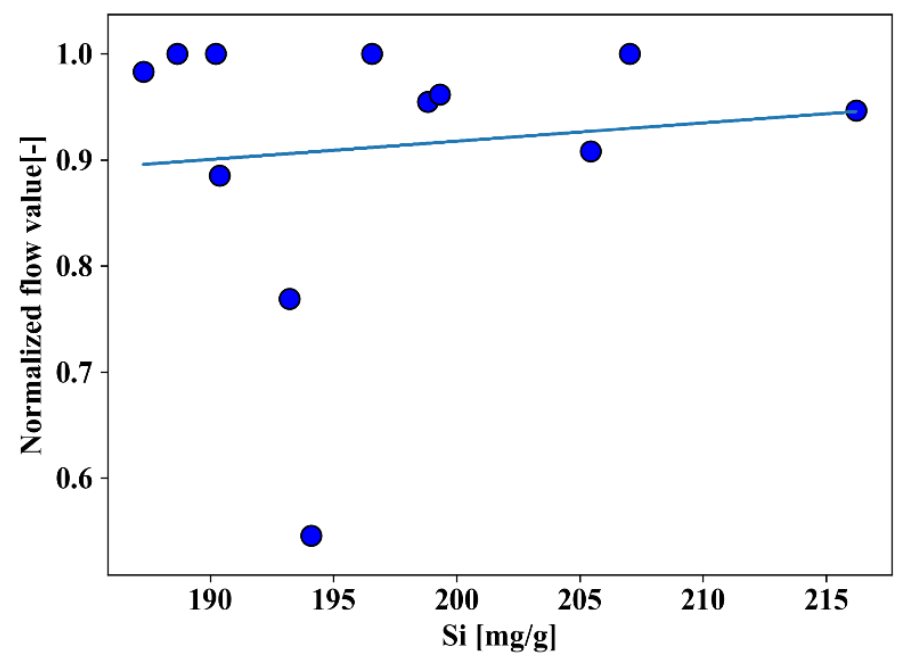

Figure 20 Relationship between Si concentration and normalized slump flow value 


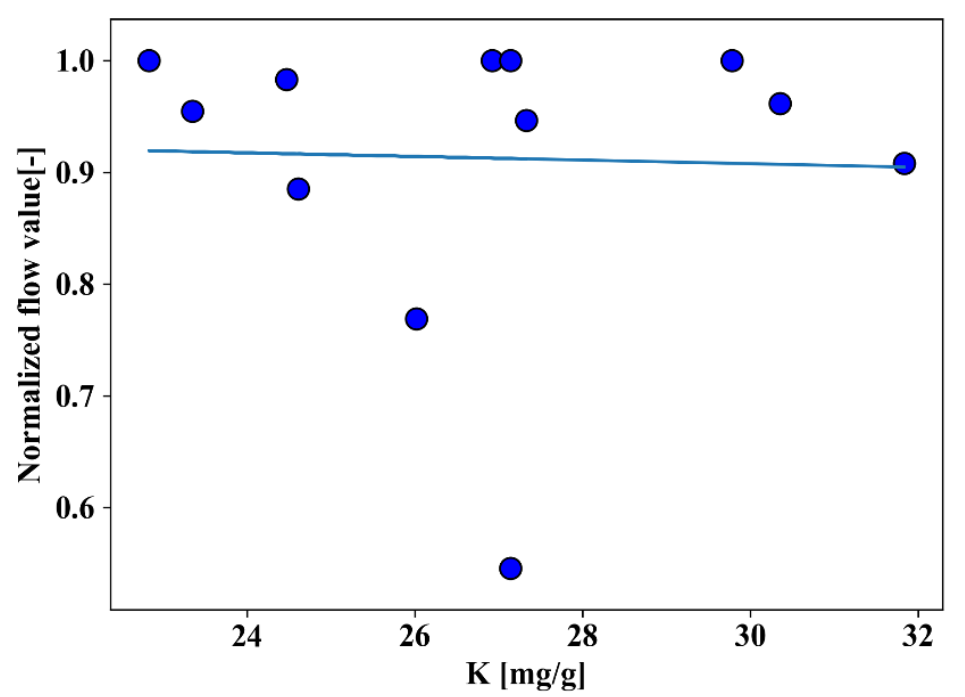

Figure 21 Relationship between K concentration and normalized slump flow value

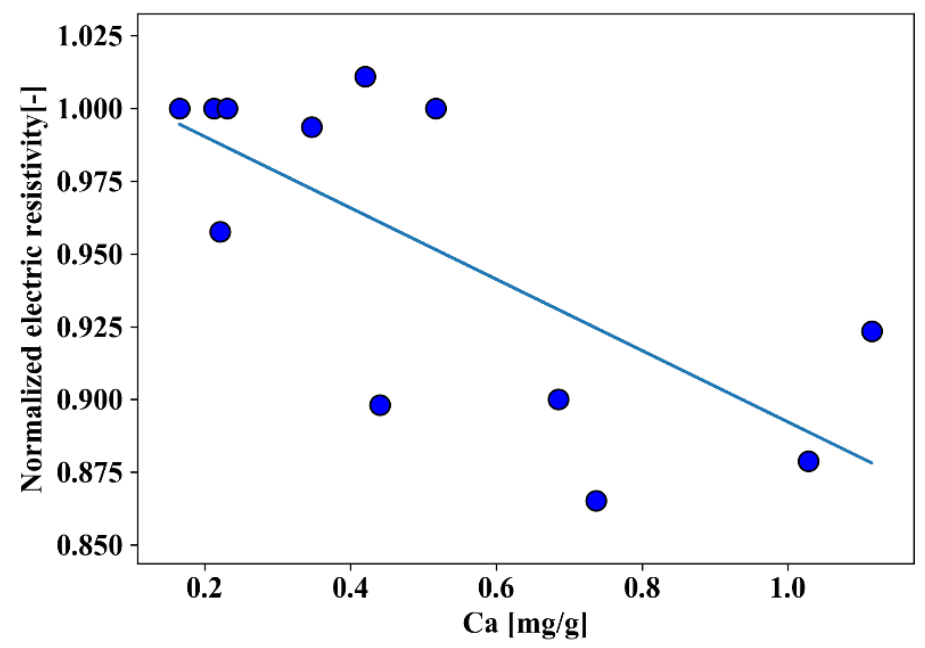

Figure22 Relationship between Ca concentration and normalized electric resistivity

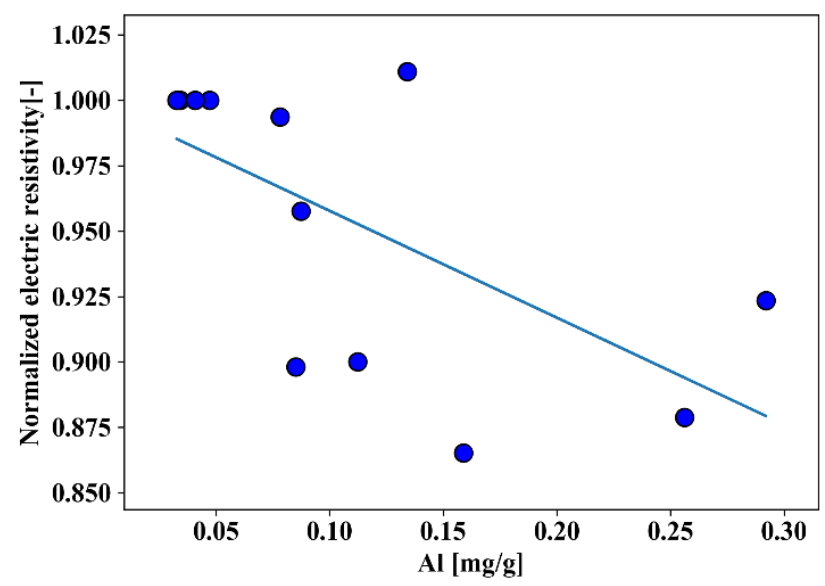

Figure23 Relationship between $\mathrm{Al}$ concentration and normalized electric resistivity 


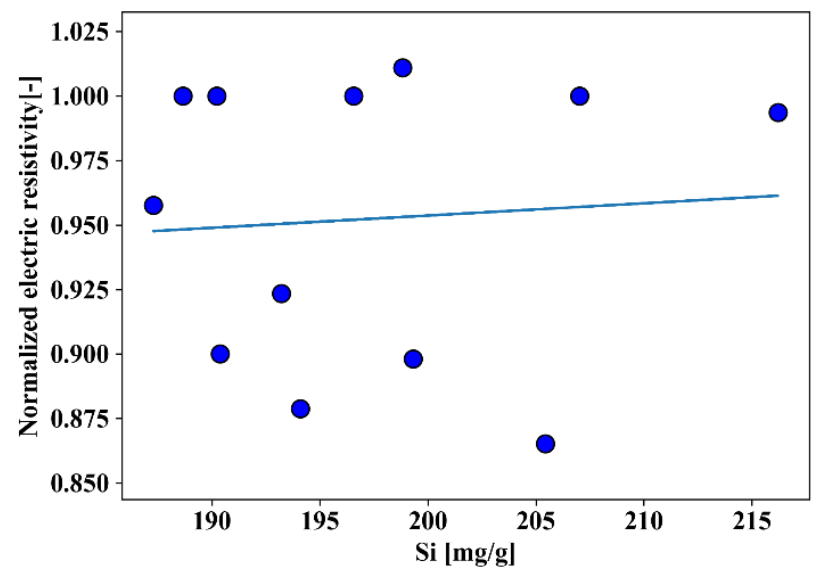

Figure 24 Relationship between Si concentration and normalized electric resistivity

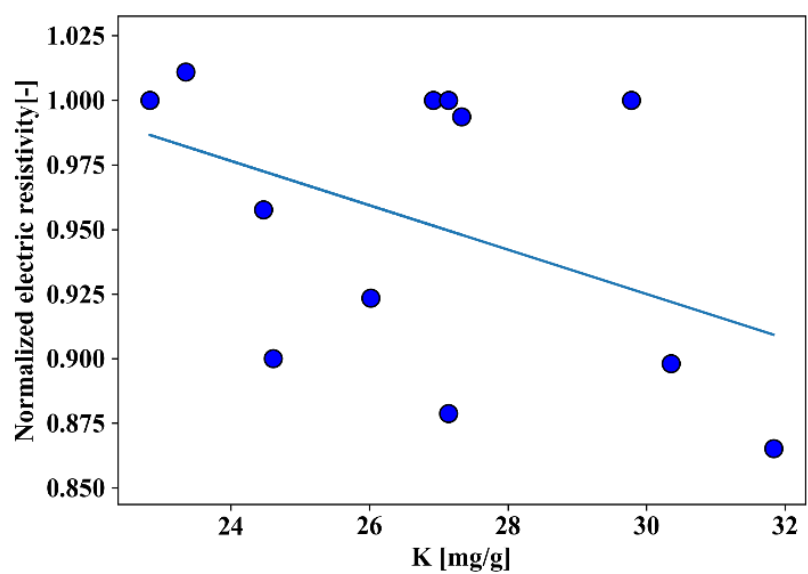

Figure 25 Relationship between K concentration and normalized electric resistivity

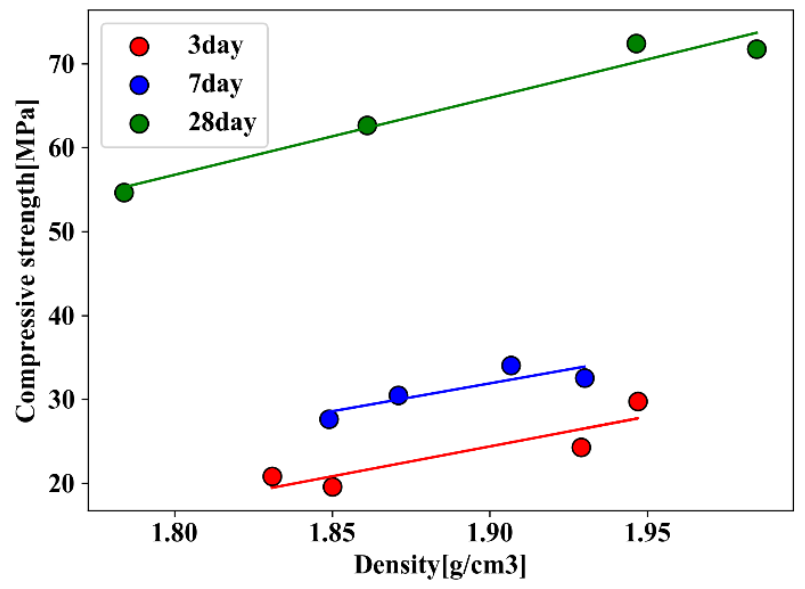

Figure 26 Relationship between density and compressive strength 


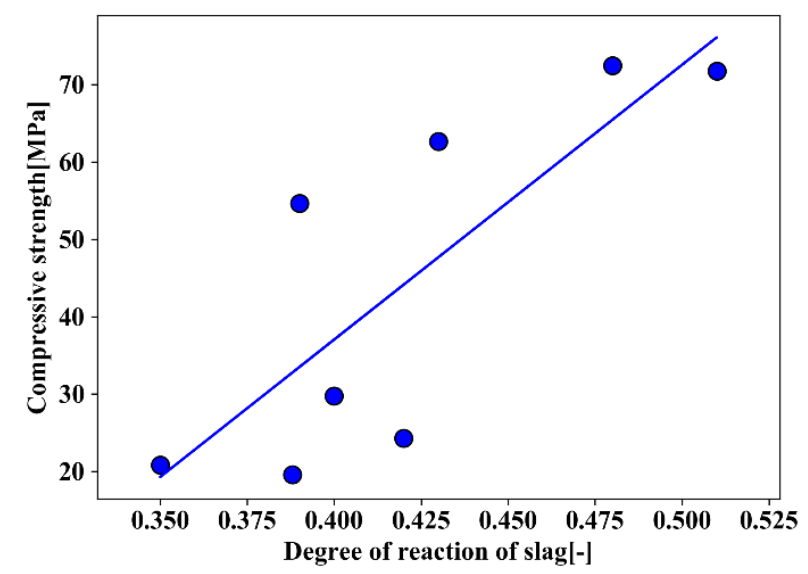

Figure 27 Relationship between degree of reaction of slag and compressive strength

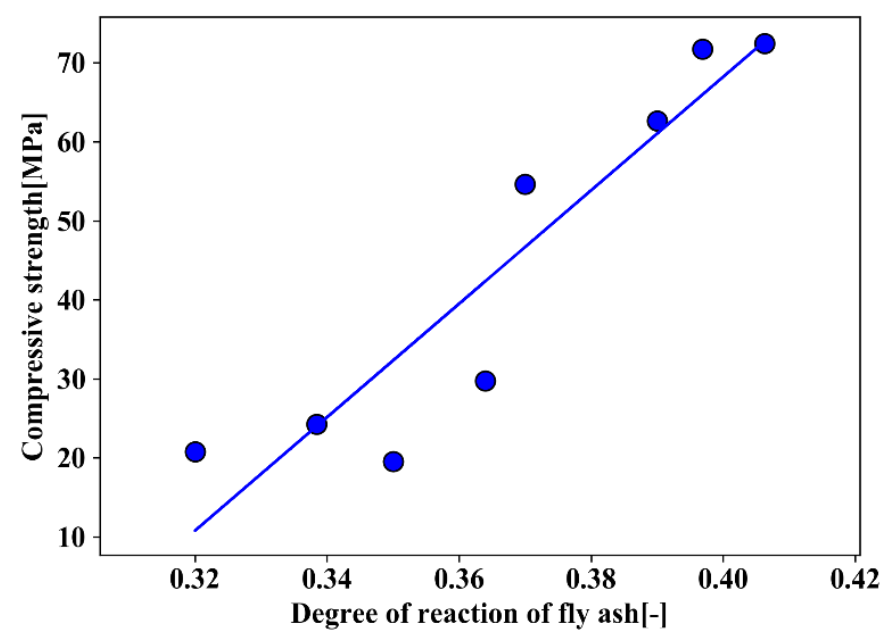

Figure 28 Relationship between degree of reaction of fly ash and compressive strength

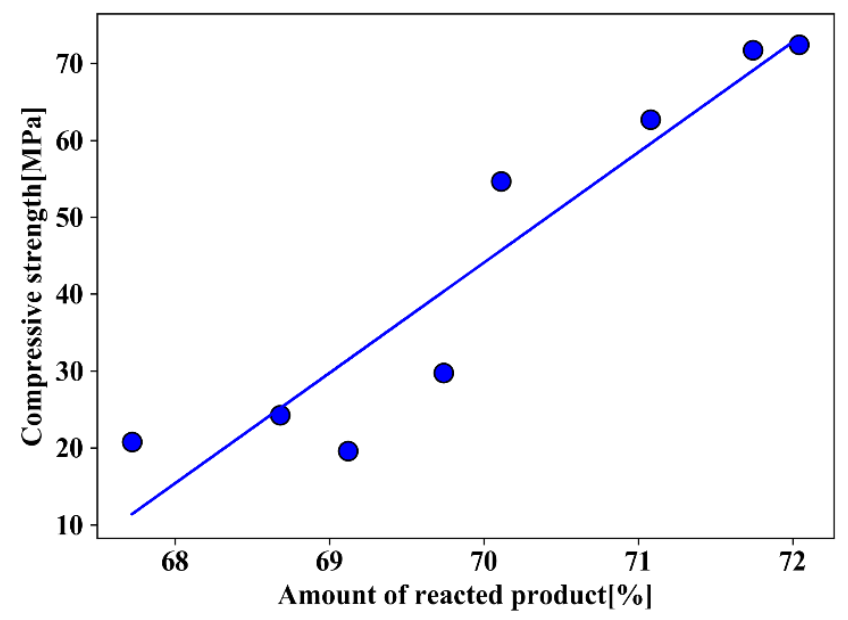

Figure 29 Relationship between amount of reacted product and compressive strength 


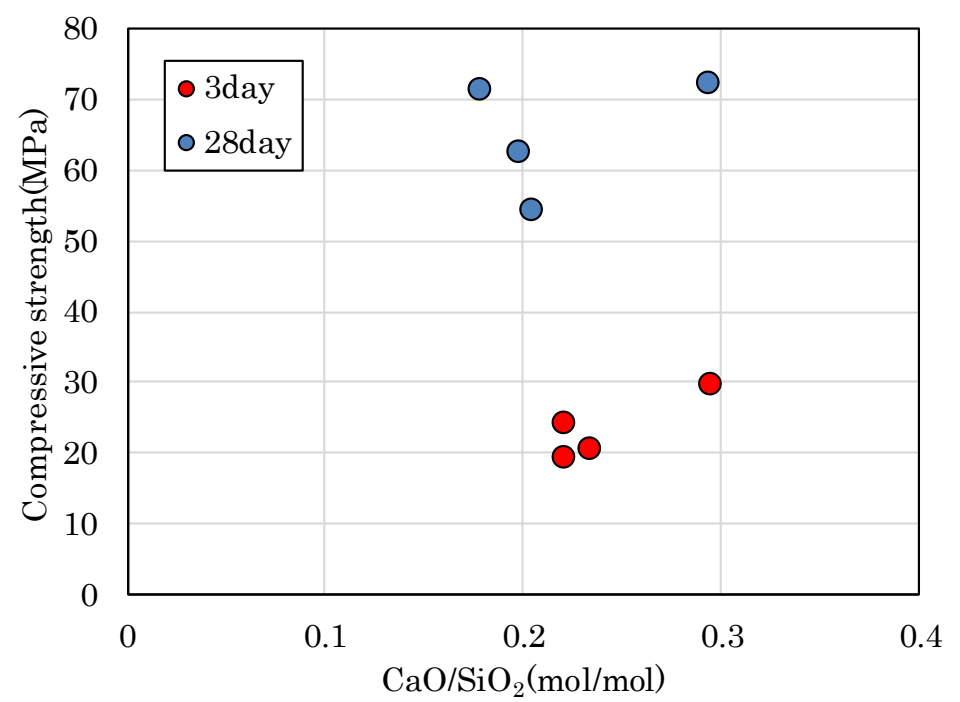

Figure 30 Relationship between $\mathrm{CaO} / \mathrm{SiO}_{2}$ and compressive strength

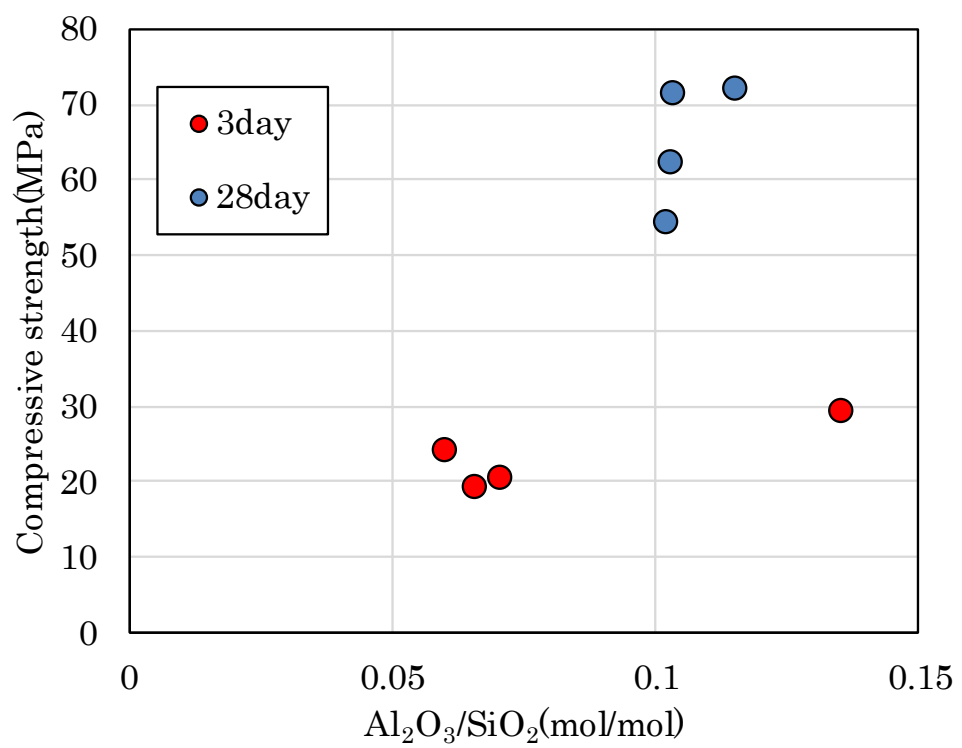

Figure 31 Relationship between $\mathrm{Al}_{2} \mathrm{O}_{3} / \mathrm{SiO}_{2}$ and compressive strength 5 


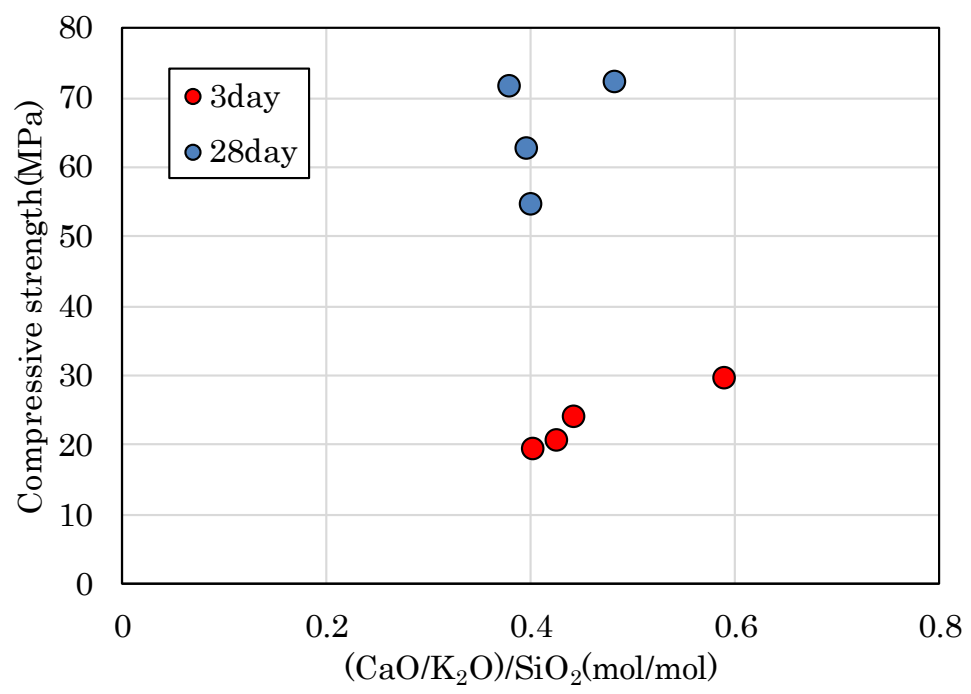

Figure 32 Relationship between $\left(\mathrm{CaO}+\mathrm{K}_{2} \mathrm{O}\right) / \mathrm{SiO}_{2}$ and compressive strength 8 